\title{
Waste Management in Rengging Village, Pecangaan District, Jepara Regency
}

\author{
Hartuti Purnaweni \\ \{hartutipurnaweni@gmail.com\} \\ Universitas Diponegoro, Indonesia
}

\begin{abstract}
Waste is residual materials disposed as by-products, a serious problem to tackle. This study focused at rural waste management in Rengging Village, Pecangaan District, Jepara Regency. This study analyzed the environmental and waste management conditions in Rengging, using a descriptive qualitative research method. The primary data was collected from leading informants of regencies and rural government offices, as well as the local villagers, used questionnaires, in-depth interviews, observation and library study. The findings are as follows: $3-\mathrm{R}$ waste management had not been applied in Rengging. More than 56\% local people burn their waste in open space, $22 \%$ just dump the waste, $2 \%$ dump after sorting the waste, $10 \%$ dump it in drainage; $10 \%$ burn and dump, or reuse it for fertilizers or dispose in non-private open spaces. It is recommended that the local people need socialization about the importance of good waste management. The village administration should make Rengging waste regulation, and cooperate.
\end{abstract}

Keywords: Waste Management, Rural, Burn the Waste.

\section{Introduction}

Waste has become a major problem faced by big cities in Indonesia. Waste are used and disposed materials because the users, i.e. humans, no longer need them. Wastes are always present in daily life. Each year, waste volumes continue to grow higher due to many factors, such as population growth, inadequate waste containers and disposal sites, lacking capacity in waste management, poor knowledge about benefiting from the wastes, and reluctantly to exploit the wastes as useful by-products due to their negative association to dirty and unhealthy materials. These factors will therefore contribute to the decreasing quality of the environment and human life [1].

Poorly managed wastes make environment dirty and shallow river beds, leading to flood. Furthermore, poor management increases the possibility of diseases, bad odors, and inconvenience [2].

Waste-related problems can be divided into three different domains, i.e. downstream, process, and upstream. At the downstream domain waste disposal continues to grow; at the process domain community and government resources are limited; and at the upstream domain final processing is inadequate [3]. Most of population believe that burning wastes is a better solution for waste management. They do not think about the negative impact of the burning activity, which is polluting the affected environment and reducing health quality. This attitude likely depends on knowledge and age maturity [3]. 
Law Number 18/2008 on Waste Management and Government Decree Number 81/2012 require the need for the change in fundamental paradigm towards waste management from Collect-Transport-Dispose to waste processing by waste reduction and management. This change has been particularly imminent. The paradigm that considers waste as resources with economic value and benefit is preferable because it leads to the waste reuse and recycle into valuable materials, such as energy, fertilizers, and industrial raw materials. Waste processing can apply a comprehensive approach, in which it becomes a priority issue right form the upstream, where products are identified as potential wastes, to the downstream domain, in which the products have been used and disposed as waste, and, then, returned to the environment in a safety manner [4].

Results from a study performed in sub-urban area in Sri Lanka reveal that waste management in the research site becomes the responsibility of the city health department [5]. It indicates that local citizens work in concert with the surrounding city governments in waste management. In case of rural area, local population will find it easier to manage the wastes because they were predominantly biodegradable. In addition, rural population have more spaces on which the waste can be processed [6].

In terms of Indonesia, approximately $56 \%$ of the total wastes are under the management of government. The remaining portions are processed by the following methods: burning (35\%), dumping (7.5\%), decomposition (1.6\%), and other methods (15.9\%) [7]. Had the wastes been properly and professionally managed, the environment would have been a better place to live. Indeed, people continue to dispose the wastes in rivers, ponds, gardens, and other places, which are not provided for waste disposal purpose. Most people also continue to burn the wastes.

A preliminary study went on by interviewing 20 local population in Banuhampu District, resulting in $40 \%$ of the total population practicing improper waste disposal (e.g., disposing them to water ditch, valleys, and fish ponds), $25 \%$ reusing them as fertilizers and cattle feeds, $20 \%$ disposing them to the temporary disposal sites provided by the government, and $15 \%$ burning them. The data revealed that more people still did the improper practices in their waste management. Such behavior contributed to the reduction of the environmental and health quality. According to Sagune [8], motivation and incentive factors affect individual capacity in waste management institution.

Waste management has always become an important problem in public administration because it deals with public service, in particular health issue. Waste problem does not only include urban area, but also rural area.

How about waste management in rural area of Jepara Regency, especially in Rengging Village? It is interesting to analyze waste management in rural area, especially in Rengging which is located in the middle of rural area of the prominent regency famous of its many special art and cultural products such as wood carving and textile such as Jepara. Makes the regency famous also among foreigners. Good waste management, including rural waste management, will add a positive side of Jepara among foreigners.

This study aimed at identifying the environmental condition in Jepara, especially in Rengging Village, Pecangaan District, Jepara Regency, and analyzing the condition of waste management in Rengging Village. The study expected to provide an evaluation of the rural waste management in Rengging Village, to contribute alternative solution towards the quality improvement of the waste management in Rengging Village, Pecangaan District, Jepara Regency. By doing so, the study was expected to contribute the goals of local development in human development and national competitiveness through public administration process, in this case is in waste management practices. 


\section{Method}

This study used a phenomenological paradigm with a qualitative approach presented in a descriptive manner. Therefore, the study applied a descriptive qualitative research method. It focused on the exploration of waste management in Rengging Village, Pecangaan, Jepara Regency. The study collected the research data by interviewing leading informants, such as Jepara Regency Environment Office, Jepara Regency Development Plan Office (Bappeda), and Rengging Village Chief and population. To collect the data this study disseminated forms and performed an in-depth interview, which would be subjected to narrative presentation and taxonomical analysis.

\section{Results and Discussion}

Jepara Regency, Central Java Province, Indonesia, has three final disposal site (TPA), i.e. TPA Bandengan, TPA Krasak, and TPA Gemulung. These sites were divided into three different zones, as follows:

a) Zone 1 (TPA Krasak): Donorojo, Keling, Kembang, and Bangsri Districts.

b) Zone 2 (TPA Bandengan): Jepara, Kedung, Tahunan, Batealit, Mlonggo, and Pakis Aji Districts.

c) Zone 3 (TPA Gemulung): Pecangaan, Kalinyamatan, Mayong, Nalumsari, and Welahan. In Jepara Regency, waste management was still stuck on an old paradigm (collecttransport-dispose). Source reduction or waste selection did not take place properly. Even though decomposition process was available, but its availability was still inadequate. According to the Jepara Regency Environmental Office (2018), the regency produced a total of 1,128 tons/day wastes and the Regencial Landfill (TPA) could only accommodate 120 tons/day. In other words, more than 1,000 tons wastes were left abandoned. This situation would get worse if the local people misconducted behaviors remain. In turn, it might also result in health disorders and environmental damage.

In terms of legislation, Jepara Regency had already had a Local Decree on Waste Management Number 3/2009 on Waste Management in Jepara Regency. The decree divides waste into the following categories: (a) Household wastes; (b) Household-like wastes; (c) Specific wastes.

Household wastes under article (1.a) derive from daily activities of the households, excluding those from defecation and specific wastes. Household-like wastes according to article (1.b) consist of those resulted from commercial area, industrial site, exclusive zone, social and economic facilities, and any other facilities.

According to the Environmental Office of Jepara Regency, 60-70\% of the wastes were organic, and $40 \%$ of them were inorganic. The following Table presents the waste composition in Jepara Regency (Table 1). The Environmental Office of Jepara Regency also reports that according to a study performed by PTMP every individual produced $0.57 \mathrm{~kg}$ waste daily. The waste dumping volumes were approximately 1,128 tons/day, whereas those being transported to the final disposal site were 120 tons/day. It indicated an inefficient waste transport. There were more than 10,000 tons of wastes that had a potential to be dumped every day. Technically, the operational factors that affected such problem included lacking waste transporting vehicles, inadequate operational cost, and trip beyond schedules from the temporary to the final waste disposal sites. 
Table 1. Waste Composition in Jepara Regency

\begin{tabular}{clc}
\hline No & \multicolumn{1}{c}{ Composition } & Percentage $(\%)$ \\
\hline 1 & Organic & 60.00 \\
2 & Inorganic & 20 \\
& - Low-grade inorganic & 10 \\
& - Commercial inorganic & 10 \\
\hline & - B3 Wastes & 100.00 \\
\hline \multicolumn{2}{c}{ Total } \\
\hline
\end{tabular}

The regency's landfill or TPA in Jepara is incapable to accommodate all of the produced waste. Therefore, the environment, such as gardens, rivers, and open spaces therefore become waste dumping sites. This study found the similar situation in Rengging Village, where any legislation in waste management was still absent. On one hand, the village administration had not paid a serious attention to the waste-related issues. Similarly, the local population do not have a serious awareness of the similar issues. Waste issue in Rengging Village became a difficult problem to solve for the Jepara Regency Government and was imminent to observe in academic domain.

Building popular awareness is not easy. Mutual efforts are necessary, in which the government, civil society, and third parties work in concert. In short, it takes time. Practical examples are effective to generate positive and consistent attitudes among the citizens in concern. A direct socialization about waste management is useful to enhance popular participation.

Rengging is a $4.38 \mathrm{~km}^{2}$ village under the administration of Pecangaan District, which is located in the southern part of Jepara Regency with immediate border of Batealit District. The village sits $<500 \mathrm{~m}$ above the sea level with average temperature of $23-32^{\circ} \mathrm{C}$ and annual rainfall of $300 \mathrm{~mm}$. The administrative are of Rengging Village consists of 3 Rukun Warga (RW) and 21 Rukun Tetangga (RT). By 2017, the village became the residence for 7,152 population with population density rate of $1,660 \mathrm{ind} / \mathrm{km}^{2}$

Table 2. Number of Rengging Population by Age Group in 2017

\begin{tabular}{cccc}
\hline Age Group (years old) & Male & Female & Total \\
\hline $0-4$ & 339 & 329 & 668 \\
$5-9$ & 323 & 311 & 634 \\
$10-14$ & 322 & 284 & 606 \\
$15-19$ & 319 & 324 & 643 \\
$20-24$ & 336 & 326 & 662 \\
$25-29$ & 310 & 299 & 609 \\
$30-34$ & 286 & 283 & 569 \\
$35-39$ & 259 & 283 & 542 \\
$40-44$ & 229 & 234 & 463 \\
$45-49$ & 202 & 228 & 430 \\
$50-54$ & 215 & 184 & 399 \\
$55-59$ & 170 & 171 & 341 \\
$60-64$ & 140 & 131 & 271
\end{tabular}




\begin{tabular}{cccc}
\hline Age Group (years old) & Male & Female & Total \\
\hline 65 and older & 184 & 131 & 315 \\
\hline Total & 3,634 & 3,518 & 7,152 \\
\hline \multicolumn{2}{c}{ Source: Jepara Regency Statistical Office, 2018.}
\end{tabular}

The majority citizens of Rengging Village make their livings as peasants and factory labors. The village is the home for 1,756 houses with the average family member of 4 individuals. There are 21 stores, two large industrial factories, eight medium-size industries, 36 small-size industries, and 52 households. The higher the economic level of a community, the higher the consumption rate its citizens. Therefore, the more wastes to be produced.

In reference to the Jepara Regency Environment Office, Rengging Village produced 4,076.46 kilograms of wastes daily. In other words, there were potentially 4,000 kg wastes left abandoned in Rengging, which had a prospect of causing environmental damage because the village had not had temporary waste disposal (TPS) and waste transporting vehicles. In practice, the waste management in Rengging Village was far below preferable standards. The observation resulted as follows:

$\underline{\text { Table 3. Technique of Waste Management in Rengging Village }}$

\begin{tabular}{ccc}
\hline No & Technique & Frequency \\
\hline 1 & Burning & 56 \\
2 & Dumping & 22 \\
3 & Selection & 2 \\
4 & Water dicts disposal & 10 \\
5 & Others & 10 \\
\hline & Total & 100 \\
\hline
\end{tabular}

Source: Post-processing primary data, 2019.

The above table reveals that more than $50 \%$ of the total population in Rengging Village burnt the wastes in open spaces, $22 \%$ dumping them, $2 \%$ selecting them, $10 \%$ disposing them into water dicots, and $10 \%$ disposing them to their private open spaces. These realities explained the misconducted behaviors of the local population in the village towards waste management by ignoring threats on either environment or public health.

Due to the absence of any waste disposal sites, the local population of Rengging Village disposed their wastes to improper places nearby their homes. Therefore, the waste process selection became extremely difficult. As the village did not provide any temporary disposal site, the large-scale waste disposal did a great The quality of civil society participation in the technical activities in waste management in Rengging Village needed strong awareness of environmental sustainability. The study indicated such lacking participation from the following aspects: (a) Lacking awareness of putting the 3R method in practice; (b) Improper manner in waste disposal, e.g. misuse of open spaces; (c) Habits in using non-degradable materials; (d) Lacking awareness of clean life, in particular planning, implementation, and monitoring.

During the research observation, the study found $70 \%$ organic wastes and $30 \%$ plasticcontained wastes. More than $90 \%$ of the respondents admitted that they used plastics in daily activities. Most of the plastics were derived from used packs $(35 \%)$, drinking water bottles $(15 \%)$, snacks $(14 \%)$, laundry packs $(15 \%)$, other packs $(12 \%)$, industrial packs $(10 \%)$, and 
catering (1\%). The commercially valued inorganic wastes were typically dumped before being sold to the collectors who fetched the wastes weekly. Whereas low grade inorganic wastes such as plastics and diapers were disposed to the private open or burnt. The local people also used to dump the wastes under the soil.

There was a time when waste management in Rengging Village was under the management of the youth union (Karang Taruna), which consisted of 10 to 15 personnel. The union established a waste bank program to collect the organic wastes that had economic value to the collectors. However, this program was not successfully implemented in all areas of the village for only three RTs $(10,20,21)$ really did it practically. The program was initiated to change the popular stigma that wastes were useless and to motivate them to exploit the wastes economically.

However, the waste bank program stopped because of lacking personnel and inadequate operational cost. To make worse, the village administration could not help provide adequate facilities and infrastructures. The whole process of the program was funded voluntarily by the youth union. According to its committee members, in 2016 the youth union proposed a program funding to the village administration as much as 16 million rupiahs but not qualified. In 2017, the village administration granted 4 million rupiahs from the Village Budget. However, the funding never was materialized to help implement the waste bank program.

Rengging Village did not have any legislation on the waste management. The village administration had not prioritized the importance of environmental cleanliness and health. However, they promised to be ready of accommodating any initiative concerning the legislation on waste management. So, any programs related to waste management had never been materialized. The waste management discourse had popular among the villagers but never been put into practice as no real stakeholders had initiatives.

In Rengging, such as in other villages in Jepara Regency, no legislation on waste management exist yet. The Jepara Regency Environment Office prepared a legislation draft and expected that every village would have legislation on waste management in such that the local population were motivated to be more aware of health and environment quality. At the moment, Local Decree Number 3/2009 on Waste Management in Jepara Regency was shadowed by complex problems as many people had not understood the contents of the decree. The Regging Village administration only knew that the Local Decree was available, but did not know anything about its contents. Therefore, Jepara Regency Government and Jepara Regency Environment Office were making efforts to remedy and to adjust the content of the Local Decree Number 3/2009 on Waste Management in Jepara Regency.

Waste issue is complex. Therefore, interrelationship between stakeholders is necessary to educate the importance of environmental quality in Rengging Village. Most local people in the village still lacked of awareness compared to those in urban area in Jepara Regency. Waste reduction through $3 \mathrm{R}$ pilot program is in accord with the Decree of the Minister of Public Works Number 21/PRT/2006.

Concerning the waste management system, the management basis must focus on minimizing the wastes and using them as energy source. The successful waste and using them as energy source. The successful waste management depends on good awareness of the community because their behavior is an important variable. The community participation in waste management needs for improvement through the $3 \mathrm{R}$ based waste management.

The legislation must involve authorities and responsibility of the environment managers as well as people at large and retribution. The village legislation is a fundamental basis on which the followings are implemented [9]:

a) Public tranquility related to waste processing. 
b) Masterplan of waste management in Rengging Village.

c) Managing institution and organization.

d) Regulations for management implementation.

e) Service tariffs and retribution.

f) Co-operation between stakeholders, i.e. government, civil society, and private sector.

Environmental administrators must focus on the improvement of the institutional performance in the waste management and strengthening of regulator and operator functions. The targets to be achieved must be capable of incorporating the community participation in reducing the wastes from their very sources as an application of the new paradigm other than end of pipe system.

\section{Conclusion}

The waste management in Rengging Village had not implemented the 3R-based waste management system. The local community of the village practiced the waste management by burning in open spaces (56\%), dumping (22\%), selection (2\%), disposal to water ditch $(10 \%)$, and disposal by burning and dumping $(10 \%)$, processed as fertilizers and disposed to private open spaces.

Settlement management must focus on the improvement of waste managerial institution and strengthening regulator and operator functions. The targets should be oriented to a fully capable institutions and system in managing and providing services related to waste issue and retribution under the consent of 3R (SNI 3242-2008). Vary legal products requiring the waste management are expected to help regulate the waste management in which all elements participate actively and be aware of environmental health.

The facts indicated lacking awareness of the local community towards good and proper waste management. In some neighborhoods (RT), youth union had initiated a waste bank program, but the program was discontinued due to lacking personnel, operational cost, and supports from local authority. Rengging village administration had not had any legislation on the waste management. The legislation and budget for waste management would be made available by the support of initiators.

\section{References}

[1] I. S. L. Tobing, "Dampak sampah terhadap kesehatan lingkungan dan manusia," Makal. pada Lokakarya Aspek Lingkung. dan Leg. Pembuangan Sampah serta Sos. Pemanfaat. Sampah Organik sebagai Bahan Baku Pembuatan Kompos. Kerja sama Univ. Nas. dan Dikmenti DKI. Jakarta Juni, 2005.

[2] M. Hakim, J. Wijaya, and R. Sudirja, "Mencari Solusi Penanganan Masalah Sampah Kota," Bandung Direktorat Jenderal Hortik. DEPTAN RI, 2006.

[3] S. A. Mulasari, "Hubungan tingkat pengetahuan dan sikap terhadap perilaku masyarakat dalam mengolah sampah di Dusun Padukuhan Desa Sidokarto Kecamatan Godean Kabupaten Sleman Yogyakarta," J. Kesehat. Masy., vol. 6, no. 3, pp. 144-211, 2012.

[4] A. S. Suryani, "Peran bank sampah dalam efektivitas pengelolaan sampah (studi kasus bank sampah Malang)," J. Aspir., vol. 5, no. 1, pp. 71-84, 2014.

[5] N. J. G. J. Bandara and J. P. A. Hettiaratchi, "Environmental impacts with waste disposal practices in a suburban municipality in Sri Lanka," Int. J. Environ. Waste Manag., vol. 6, no. 12, pp. 107-116, 2010. 
[6] S. Chimbuya, "A Conceptual Framework for Urban Environmental Planning and Management," Int. Counc. Local Environ. Initiat., 2012.

[7] Y. Thrihadiningrum, "MDGs Sebentar Lagi Sanggupkah Kita Menghapus Kemiskinan di Dunia," Jakarta PT Gramedia, 2010.

[8] J. M. Sagune, "Faktor Pembentuk Kapasitas Individu Dalam Kelembagaan Pengelolaan Persampahan Di Kota Tahuna Kabupaten Sangihe.” Universitas Diponegoro, 2009.

[9] B. Lokahita and E. Damanhuri, "Potensi Sampah Combustible pada Titik Transfer di Kota Bandung untuk Bahan Baku Refused Derived Fuel (RDF).” Program Studi Teknik Lingkungan FTSL ITB. Bandung, 2013. 